\title{
STUDY ON VENTILATION IN ENCLOSED POULTRY HOUSES
}

\author{
Mohamed A. Abd El-Rahman", M.S. El Shal, M.K. Abd El-Wahab \\ and Mona M. Abd El-Aziz
}

Agric. Eng. Dept., Fac. Agric., Zagazig Univ., Egypt

\begin{abstract}
Increasing air movement over poultry at high ambient temperatures by using ventilation has become an accepted means of reducing environmental heat stress over the last several years. The present study was carried out to evaluate the effect of air velocity and ambient temperature on broiler performance under a constant RH of $58 \%$ and limited the optimum air velocity, ambient temperature and area house section to achieve the best broiler performance. The main experiments were conducted under four air velocities of 1, 1.5, 2.5 and 3m/sec., four ambient temperatures of $28,30,32$ and $35^{\circ} \mathrm{C}$ and two area house sections of $12 \times 2.7$ and $12 \times 3 \mathrm{~m}^{2}$ at 4, 5, 6 weeks of age taking into consideration body weight, feed intake, feed conversion ratio, mortality rate, production efficiency factor (PEF) and specific energy. The obtained data showed that the highest rates of weekly broiler performance where recorded under air velocity of $2.5 \mathrm{~m} / \mathrm{sec}$., ambient temperature below $28^{\circ} \mathrm{C}$ and area house section of $12 \times 2.7 \mathrm{~m}^{2}$.
\end{abstract}

Key words: Ventilation, poultry, mortality rate, production efficiency factor.

\section{INTRODUCTION}

The poultry industry is one of the main agricultural industries in Egypt, where investment in this industry is about LE 25 billion, the size of the labor force is about 1.5 million permanent workers and about 1 million temporary workers and the annual production is 1 billion broilers and 8 billion table eggs (National Laboratory for Veterinary Quality Control on Poultry Production, 2013).

The poultry industry not only supplies animal protein for feeding the human population, but is also linked to other industries such as animal feed, medicine and veterinary inputs.

Heat stress often is a common problem in such countries. Therefore, it requires the provision of environmental conditions suitable for the growth speed of the bird so that reduce the impact of heat stress (Dozier et al., 2006).

Air movement is one of the most effective methods of cooling birds during hot weather. As air moves over a bird's hot body, heat is removed from the bird, making it feel cooler (Lacy and Czarick, 1992).

Furlan et al. (2000) evaluated the effect of air velocity on body surface and rectal temperature of broiler chickens. Male broiler chickens aged 36 to 42 days were exposed to five different air velocities of (5.7, 4.2, 3.1, 2.4 and $1.8 \mathrm{~m} / \mathrm{sec}$.). The results suggest that air velocity of 2.4 $\mathrm{m} / \mathrm{sec}$., in air temperature of $29^{\circ} \mathrm{C}$, improve heat loss in the birds.

Al-Helal (2003) studied the environmental control practices and problems for poultry. The results obtained from this study indicated that summer ventilation rate was able to give a total air exchange between (0.80 and 1.51) every minute, and between (0.31 and 0.46 ) every minute for winter.

Yahav et al. (2004) illustrated the effect of air velocity on performance of 4 to 7 week old broiler chickens, an experiment was conducted using four different air velocities $(0.8,1.5,2.0$

\footnotetext{
Corresponding author: Tel. : +2 01065549219

E-mail address: eng.abdelshafy@yahoo.com
} 
and $3.0 \mathrm{~m} / \mathrm{sec}$.) at constant ambient temperature $\left(35 \pm 1.0^{\circ} \mathrm{C}\right.$ ). They found that air velocity of 2.0 $\mathrm{m} / \mathrm{sec}$, enables broilers to maintain proper performance together with efficient thermoregulation and water balance under harsh environmental conditions.

Abu-Dieyeh (2006) mentioned the effect of high temperature on growth performance of broilers. He used two ambient temperatures (20 $\pm 1^{\circ} \mathrm{C}$ and $35 \pm 1^{\circ} \mathrm{C}$ ) until 8 weeks. of age. He found that body weight, feed intake, and feed conversion ratio were significantly reduced in broilers at $35 \pm 1^{\circ} \mathrm{C}$. These results indicated that high ambient temperature caused a significant effect on growth rate depression rather than reduction in feed intake of heat exposed broilers.

Yahav (2007) studied the effects of air velocity on body weight of broiler chickens at the ages of 5, 6 and 7 weeks, following exposed to 35,30 and $25^{\circ} \mathrm{C}$, respectively, and to $60 \%$ relative humidity. He found that air velocity dramatically affects the body weight of broiler chickens exposed to different environments. Broilers exposed to air velocity of $2.0 \mathrm{~m} / \mathrm{sec}$, had exhibited significantly higher body weight and feed intake than those exposed to lower air velocities (0.8 and $1.5 \mathrm{~m} / \mathrm{sec}$.).

Akyuz (2009) studied the effect of some climate parameters of environmentally uncontrollable broiler houses on broiler performance. He found very significant differences in broiler performance during the summer and winter as a result of environmentally uncontrolled in broiler houses, where the mortality ratio in summer and winter found to be 2.18 and $5.5 \%$, at the end of 42 days trail, the live weight of broiler found to be 2042 and 1088 grams in summer and winter months, and feed conversion ratio was found to be 1.66 and 2.15 in summer and winter months.

So, it is necessary to study the effect of the main environmental parameters affecting broiler performance (ambient temperature and air velocity), Where that reduce the temperature and increasing air velocity over broilers by using tunnel ventilation has become an accepted means of reducing environmental heat stress over the last several years. Hence, the objectives of this study are:
1.Limit the proper air velocity and ambient temperature to achieve the best broiler performance.

2.Choose the most appropriate area house section to achieve the best performance rate.

\section{MATERIALS AND METHODS}

\section{Materials}

\section{Housing and experimental procedure}

This study was performed on an environmentally controlled conditions modern broiler houses located in the poultry farm of Dakahlia Poultry Company in Behara Governorate, Egypt through summer seasons of 2013 and 2014. The poultry farm consists of eight houses. Building characteristics are presented in Table 1.

\section{Broiler chickens specifications}

In each experiment, a total of 18000 one dayold Cobb broiler chicks were placed in houses with the same characteristics and grown in a common environment until 42 day of age.

\section{Feed ingredients}

Rearing management and composition of diets in both houses at each season were similar. All the broiler chickens fed with a basal cornsoybean meal diet during 1 to 42 day of age.

\section{Equipment}

Specifications of equipment which used in this study are as follow:

\section{Ventilation system}

Tunnel ventilation system with a negative pressure was used in this study, Tunnel ventilation is a system where exhaust fans are located at one end of the house and two large openings $\left(16.6 \times 1.8 \mathrm{~m}^{2}\right)$ are installed at the opposite end. Air is drawn through these openings, down the house, and out the fans. Number of fans in each house is ten FIR Electro mechanic fans, made in Italy, voltage $230 \mathrm{~V}$, size 140 and flow rate of $40000 \mathrm{~m}^{3} / \mathrm{hr}$.

\section{Heating system}

Hot air generator system is the heating system was used in this study; Number of air heaters in each house is two Combiterm 190E 
Table 1. Building Characteristics of poultry farm

\begin{tabular}{ll}
\hline Characteristics & \\
\hline Rearing type & Floor \\
Number of houses & Eight enclosed houses \\
House width $\times$ length $(\mathbf{m})$ & $12 \times 75$ \\
House height $(\mathbf{m})$ & 2.7 and 3 \\
Housing capacity (Birds) & 18000 \\
\hline
\end{tabular}

Pericoli heater, mad in Italy, voltage $400 \mathrm{~V}$, fan air displacement $15000 \mathrm{~m}^{3} / \mathrm{hr}$., and fan electric power is $2.2 \mathrm{KW}$.

\section{Cooling system}

Evaporative cooling pad system was used in this study, area of cooling pad in each house is $60 \mathrm{~m}^{2}$, height $1.8 \mathrm{~m}$, width $33.3 \mathrm{~m}$ and thickness $15 \mathrm{~cm}$.

\section{Measuring instruments}

\section{Electronic balance}

An electronic balance was used to measure the bird's weight and the amount of feed (with accuracy of $\pm 0.05 \mathrm{~kg}$ ).

\section{Anemometer}

Anemometer kestrel 3000 was used to measure essential environmental measurements like temperature, relative humidity and air velocity.

\section{Pola HP54 steps controller}

Pola HP54 was used to measure and adjust the desired temperature, through coordination between the cooling and heating system.

\section{Methods}

The experiments were conducted in broiler farm consisting of eight broiler houses through four periods during summer seasons of 2013 and 2014. A total of 32 broiler houses ( 8 houses $\times 4$ periods). In each house using one air velocity, one ambient temperature and one area house section alternately.

All experiments were carried out at 4, 5, 6 weeks of age and broiler exposed to a constant $\mathrm{RH}$ of $58 \%$.

\section{The main experiments}

The main experiments were performed at the poultry farm to evaluate the environmental conditions affecting the performance of broiler at different ages in the summer, these environmental conditions are:

1. Four air velocities of 1, 1.5, 2.5 and $3 \mathrm{~m} / \mathrm{sec}$.

2. Four ambient temperatures of 28, 30, 32 and $35^{\circ} \mathrm{C}$.

3. Two area house sections of $12 \times 2.7$ and $12 \times 3 \mathrm{~m}^{2}$.

\section{Measurements}

\section{Body weight (gram/bird)}

At the end of each experiment 5\% of birds weighed as group using a $50 \mathrm{~kg}$ - balance. The total weight is divided by the number of weighed birds

\section{Feed intake (gram/bird)}

Feed intake is calculated for each treatment. At the end of the experiment, the residual amount of feed was weighed and subtracted from the known weight of feed at the beginning of experiment. The product figure is divided by the total number of birds.

\section{Feed conversion ratio (gram feed/gram weight)}

Feed conversion ratio was calculated according to Wagner at al. (1983) as follows:

$$
\text { FCR }=\frac{\text { Feed intake (gram) in a given period }}{\text { Body weight gain, (gram) in the same period }}
$$

\section{Mortality percent (\%)}

Mortality rate was estimated according to Halpin (1975) by using the following formula: 


$$
\begin{gathered}
\text { Mortality percent }=\frac{\text { Number of dead chicks }}{\text { Total number of chicks }}(\%) \\
\text { Production efficiency factor (PEF) }
\end{gathered}
$$

\section{Production efficiency factor (PEF)}

The production efficiency factor value is an equation used to measure the technical performance of a broiler take into account feed conversation ratio, live ability, body weight and age at depletion where the increase of the PEF value improves performance rate for broiler. The PEF value was calculated according to Samarakoon and Samarasinghe (2012) as following:

$$
\mathrm{PEF}=\frac{\text { Body weight, }(\mathrm{Kg}) \times \text { live ability }(\%)}{\text { Age at depletion, }(\text { days }) \times \mathrm{FCR}} \times 100
$$

\section{Specific energy requirements (SER)}

Specific energy requirements can be calculated by the following equation:

$$
\mathrm{SER}=\frac{\text { Required power }(\mathrm{kW})}{\operatorname{Pro}(\mathrm{kg} / \mathrm{hr} .)}
$$

\section{RESULTS AND DISCUSSION}

The discussion will cover the obtained results under the following heads:

\section{The Weekly Broiler Body Weight}

The obtained Results in Fig. 1 show that the increase of air velocity from 1 to $2.5 \mathrm{~m} / \mathrm{sec}$., was followed with an increase in broiler body weight from 1298 to 1360 , from 1740 to 1882 and from 2130 to $2423 \mathrm{gram} / \mathrm{bird}$ at 4,5 and $6^{\text {th }}$ week of ages, respectively under constant ambient temperature of $28^{\circ} \mathrm{C}$ and area house section of $12 \times 2.7 \mathrm{~m}^{2}$. Any further increase in air velocity more than 2.5 up to $3 \mathrm{~m} / \mathrm{sec}$, weekly broiler body weight decreased from 1360 to 1283, from 1882 to 1730 and from 2423 to 2060 gram/bird, respectively under the same previous conditions. The major reason for the reduction on weekly broiler body weight by increasing air velocity from up to $3 \mathrm{~m} / \mathrm{sec}$. because it make a drop in the broiler body water balance which it is in agreement with previous study (Yahav et al., 2004).

The results showed also that the effect of ambient temperature was very clear on weekly broiler body weight when the birds exposed to low air velocities than when exposed to high velocities conditions. The obtained results show a remarkable increase on weekly broiler body weight at an ambient temperature of $28^{\circ} \mathrm{C}$.

It is also observed that air velocity is the most critical factor affected on weekly broiler body weight. The highest weekly broiler body weight of $2423 \mathrm{gram} / \mathrm{bird}$ was recorded at $6^{\text {th }}$ week of age exposing under air velocity of 2.5 $\mathrm{m} / \mathrm{sec}$, ambient temperature of $28^{\circ} \mathrm{C}$ and area houses section of $12 \times 2.7 \mathrm{~m}^{2}$ comparing with the other treatments.

\section{The Weekly Broiler Feed Intake}

From Fig. 2 which represents the effect of air velocity on weekly broiler feed intake under different temperatures in area house section of $12 \times 2.7 \mathrm{~m}^{2}$, It is noticed that the increase of air velocity from 1 to $2.5 \mathrm{~m} / \mathrm{s}$ was accompanied with an increase in broiler feed intake from 1973 to 2021, from 2973 to 3136 and from 4090 to 4431 gram/bird at 4,5 and $6^{\text {th }}$ weeks of ages, respectively under constant ambient temperature of $28^{\circ} \mathrm{C}$ and area house sections of $12 \times 2.7 \mathrm{~m}^{2}$. Any further increase in air velocity more than 2.5 up to $3 \mathrm{~m} / \mathrm{sec}$., caused a decrease in weekly broiler feed intake from 2021 to 1959, from 3136 to 3017 and from 4431 to 3999 gram/bird, respectively under the same previous conditions.

The results show that ambient temperature had very clear effect on weekly broiler feed intake, when the birds exposed to low air velocities rather compared to high velocities conditions.

In addition, it is noticed that the highest broiler feed intake of 4431 gram/bird was obtained at $6^{\text {th }}$ week of ages under ambient temperature of $28^{\circ} \mathrm{C}$, air velocity of $2.5 \mathrm{~m} / \mathrm{sec}$., and area house section of $\left(12 \times 2.7 \mathrm{~m}^{2}\right)$.

\section{The Feed Conversion Ratio}

Results in Fig. 3 show that increasing air velocity from 1 to $2.5 \mathrm{~m} / \mathrm{sec}$., improved broiler feed conversion ratio from 1.52 to 1.48 , from 1.70 to 1.66 and from 1.92 to 1.82 gram feed/ gram weight at 4,5 and $6^{\text {th }}$ week of ages, respectively under constant ambient temperature of $28^{\circ} \mathrm{C}$ and area house section of $12 \times 2.7 \mathrm{~m}^{2}$. 
Fig. 1. Effect of air velocity under different temperatures on weekly broiler body weight during summer seasons of 2013 at constant area house section of $12 \times 2.7 \mathrm{~m}^{2}$

Fig. 2. Effect of air velocity under different temperatures on weekly broiler feed intake during summer seasons of 2013 at constant area house section of $12 \times 2.7 \mathrm{~m}^{2}$ 


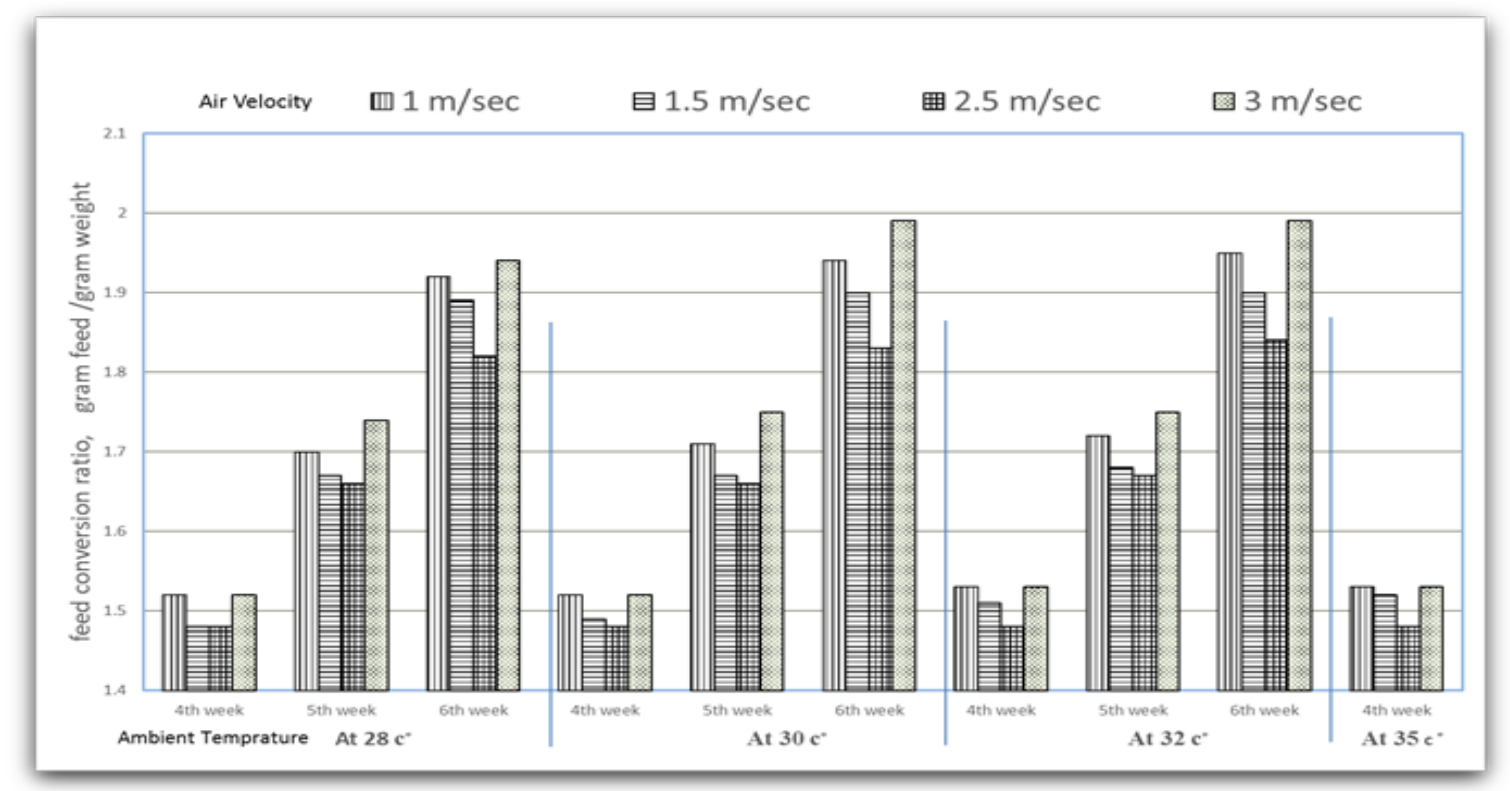

Fig. 3. Effect of air velocity under different temperatures on weekly broiler feed conversion ratio at constant area house section of $12 \times 2.7 \mathrm{~m}^{2}$

Also, the increase of air velocity more than 2.5 up to $3 \mathrm{~m} / \mathrm{sec}$., caused a worsen in feed conversion ratio from 1.48 to 1.52 , from 1.66 to 1.74 and from 1.82 to 1.94 gram feed/gram weight at 4,5 and $6^{\text {th }}$ week of ages, respectively under the same previous conditions.

The results show that the effect of ambient temperature was very clear on weekly broiler feed conversion ratio when the birds exposed to low air velocities rather compared to high velocities conditions. Results showed that increasing ambient temperature from 28 to $35^{\circ} \mathrm{C}$, at $6^{\text {th }}$ week of age caused a worsen in feed conversion ratio from 1.82 to 1.84 gram feed/gram weight, exposing to air velocity of $2.5 \mathrm{~m} / \mathrm{sec}$., and area house section of $12 \times 2.7 \mathrm{~m}^{2}$.

The highest value of weekly broiler feed conversion ratio of 1.82 gram feed/ gram weight at $6^{\text {th }}$ week of age was recorded at air velocity of $2.5 \mathrm{~m} / \mathrm{sec}$., ambient temperature $28^{\circ} \mathrm{C}$ and area house section of $12 \times 2.7 \mathrm{~m}^{2}$.

Relating to the effect of area house sections on weekly broiler feed conversion ratio, data show that there aren't clear differences between the area house section of $(12 \times 2.7)$ and $(12 \times 3)$ $\mathrm{m}^{2}$.

\section{The Weekly Broiler Mortality Percent}

The mortality percent caused a great effect by the ambient temperature, especially when the birds exposed to low air velocities rather than when exposed to high velocities conditions. The obtained results in Fig. 4 show that the highest weekly broiler mortality percent at $6^{\text {th }}$ week of age was $2.99 \%$ due to exposing to air velocity of $1 \mathrm{~m} /$ sec., ambient temperature $32^{\circ} \mathrm{C}$ and area house section of $12 \times 2.7 \mathrm{~m}^{2}$ and the least weekly broiler mortality percent at $6^{\text {th }}$ week of age was $1.1 \%$ due to exposing to air velocity of 2.5 $\mathrm{m} / \mathrm{sec}$., ambient temperature $28^{\circ} \mathrm{C}$ and area house section of $12 \times 2.7 \mathrm{~m}^{2}$.

\section{Production Efficiency Factor (PEF) and Specific Energy}

Fig. 5 shows the effect of air velocity on production efficiency factor and specific energy requirements. It is noticed that increasing air velocity from 1 to $2.5 \mathrm{~m} / \mathrm{sec}$., at $6^{\text {th }}$ week of age's leads to increase broiler production efficiency factor from 248.8 to 300.9 under constant ambient temperature of $28^{\circ} \mathrm{C}$ and area house section of $12 \times 2.7 \mathrm{~m}^{2}$. Any further increase in air velocity more than 2.5 up to $3 \mathrm{~m} / \mathrm{sec}$., broiler production efficiency factor decreased from 300.9 to 238.5 , respectively under the same previous conditions. 
Fig. 4. Effect of air velocity under different temperatures on weekly broiler mortality percent at Constant area house section of $12 \times 2.7 \mathrm{~m}^{2}$

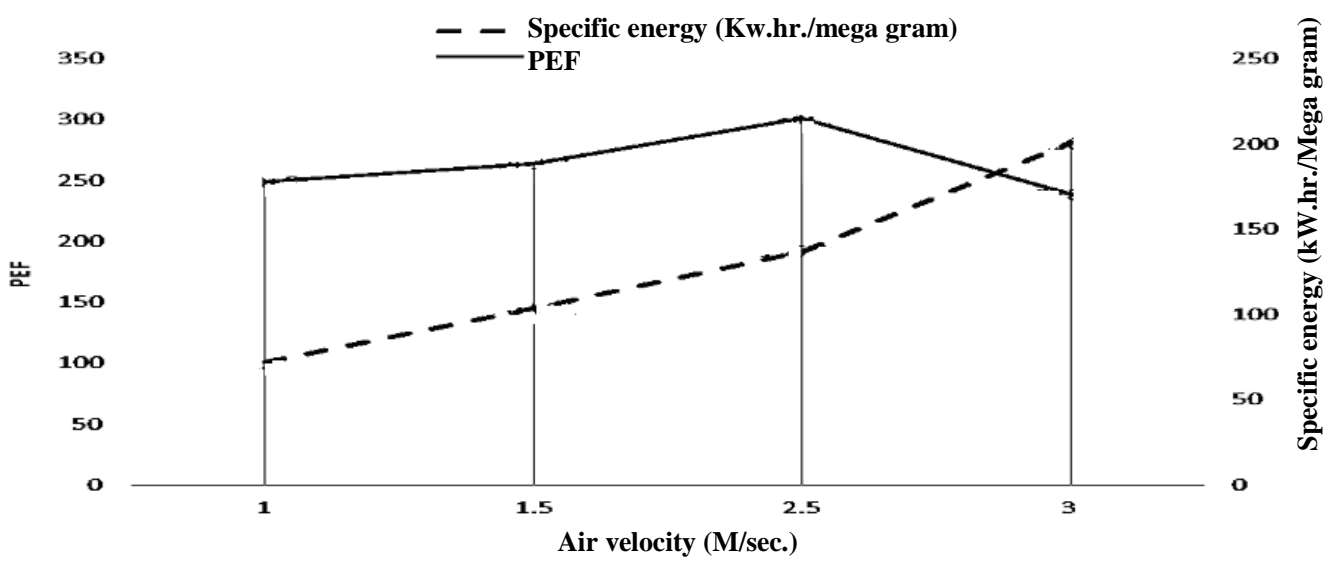

Fig. 5. The effect of air velocity on production efficiency factor and the energy requirements at constant ambient temperature of $28 \mathrm{C}^{\circ}$ and area house section of $12 \times 2.7 \mathrm{~m}^{2}$

The specific energy is highly affected by air velocity. Results in Fig. 4 show that increasing air velocity from 1.0 to $3.0 \mathrm{~m} / \mathrm{sec}$., increased energy requirements from 88.49 to $226.27 \mathrm{~kW} . \mathrm{hr} . /$ mega gram. Although the consumption a lot of energy when the air velocity of $2.5 \mathrm{~m} / \mathrm{sec}$., but we found that the rate of increase in the energy of air velocity from 1.5 to $2.5 \mathrm{~m} / \mathrm{sec}$., was less than the rate of increase in the energy of air velocity from 2.5 to $3 \mathrm{~m} / \mathrm{sec}$ also air velocity of 2.5 $\mathrm{m} / \mathrm{sec}$, achieved higher broiler production efficiency factor compared to other air velocities.
Results showed that increasing ambient temperature from $28^{\circ} \mathrm{C}$ to $35^{\circ} \mathrm{C}$ at $6^{\text {th }}$ week of age's leads to decrease broiler production efficiency factor from 300.9 to 289.8, respectively under constant air velocity of $2.5 \mathrm{~m} / \mathrm{sec}$., and area house section of $12 \times 2.7 \mathrm{~m}^{2}$. Also, the results showed that ambient temperature has no remarkable effect on energy requirements

Area house sections affect a not clearly effect on production efficiency factor, Results in Fig. 6 show that increasing area house section from 


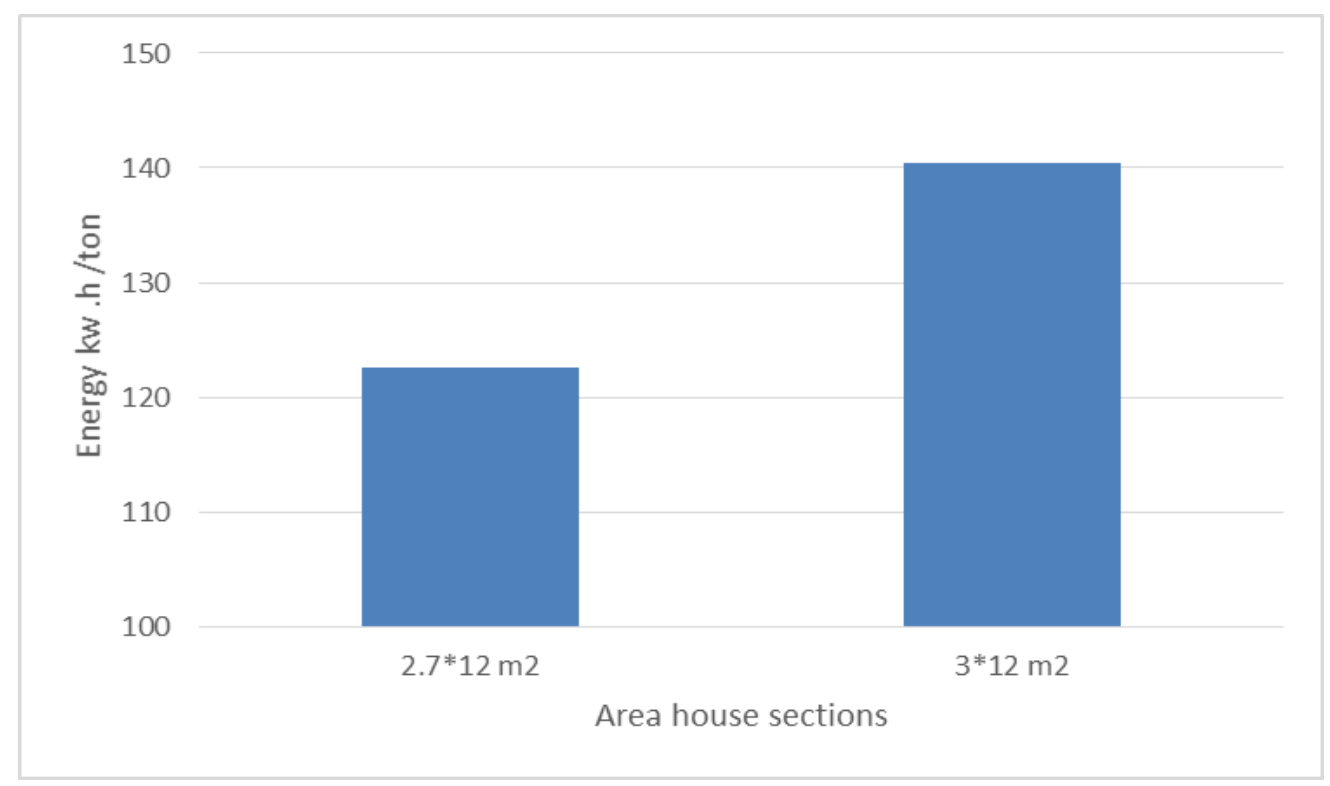

Fig. 6. Effect of area house section on energy at constant ambient temperature of $28 \mathrm{C}^{\circ}$ and air velocity of $2.5 \mathrm{~m} / \mathrm{sec}$.

$12 \times 2.7 \mathrm{~m}^{2}$ to $12 \times 3 \mathrm{~m}^{2}$ at $6^{\text {th }}$ week of age's leads to decrease broiler production efficiency factor from 300.9 to 298.5, under constant air velocity of $2.5 \mathrm{~m} / \mathrm{sec}$., and constant ambient temperature of $28^{\circ} \mathrm{C}$. But area house section affect a remarkable effect on energy requirements. Data obtained show that increasing area house section from $(12 \times 2.7)$ to $(12 \times 3) \mathrm{m}^{2}$, increased, energy requirements from 122.53 to $140.47 \mathrm{~kW} . \mathrm{hr} . /$ mega gram respectively under constant ambient temperature of $28^{\circ} \mathrm{C}$ and air velocity $2.5 \mathrm{~m} / \mathrm{sec}$.

\section{Conclusion}

The present study was performed at the poultry farm to evaluate the environmental conditions affecting the performance of broiler at 4,5 and $6^{\text {th }}$ week of ages in the summer.

From the obtained results, it can be concluded that to improve weekly broiler performance must be applied the following parameter, air velocity of $2.5 \mathrm{~m} / \mathrm{sec}$., ambient temperature below $28 \mathrm{C}^{\circ}$ and area house section of $(12 \times 2.7) \mathrm{m}^{2}$

\section{REFERENCES}

Abu-Dieyeh, Z.H.M. (2006). Effect of high ambient temperature per se on growth performance of broilers. Int. J. Poult. Sci., 5 (1): 19-21.
Akyuz, A. (2009). Effects of some climate parameters of environmentally uncontrollable broiler houses on broiler performance. J. Anim. Vet. Adv., 8 (2): 2608-2612.

Al-Helal, I.M. (2003). Environmental control for poultry buildings in Riyadh area of Saudi Arabia. J. King Saud Univ., Agric. Sci., 16 (1): 87-102.

Dozier, W.A., J.L. Purswell and S.L. Branton (2006). Growth responses of male broilers subjected to high air velocity for either twelve or twenty-four hours from thirtyseven to fifty-one days of age1. J. Appl. Poult. Res., 15: 362-366.

Furlan, R.L., M. Macari, E.R. Secato, J.R. Guerreiro and E.B. Malheiros (2000). Air velocity and exposure time to ventilation affect body surface and rectal temperature of broiler chickens. J. Appl. Poult. Res., 9:1-5.

Halpin, B. (1975). Patterns of animal diseases $1^{\text {st }}$ Ed. Veterinary Pathology, 26: 420-423.

Lacy, M.P. and M. Czarick (1992). Tunnelventilated broiler houses: broiler performance and operating cost. J. Appl. Poult. Res., 1 : 104-109.

National Laboratory for Veterinary Quality Control on Poultry Production (2013). Annual report of promising future for the Egypt Poult. Indus., Cairo, Egypt. 
Samarakoon, S.M. and K. Samarasinghe (2012). Strategies to improve the cost effectiveness of broiler production. Tropical Agric. Res., 23 (4): 338- 346.

Wagner, D.D., R.D. Furrow and B.D. Bradely (1983). Subchronic toxicity of growth promotoers in broiler chickens. Vet. Pathol., 20: 353-359
Yahav, S. (2007). The crucial role of ventilation in performance and thermoregulation of the domestic fowl. Aust. Poult. Sci. Symp., 19:14-18.

Yahav, S., A. Straschnow, D. Luger, D. Shinder, J. Tanny and S. Cohen (2004). Ventilation, sensible heat loss, broiler energy, and water balance under harsh environmental conditions. Poult. Sci., 83 : 253-258.

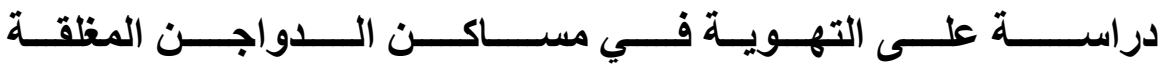

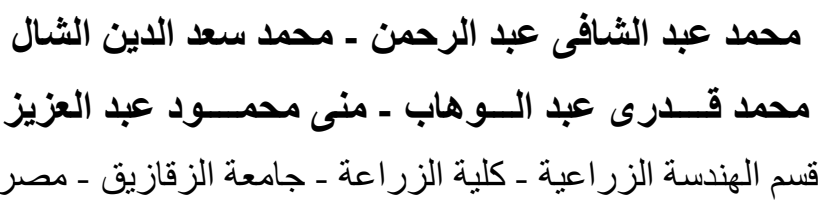

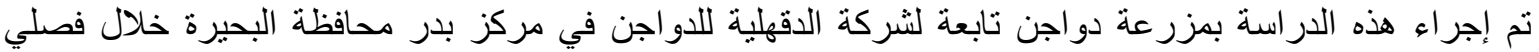

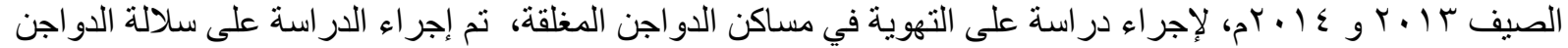

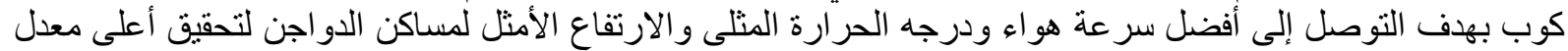

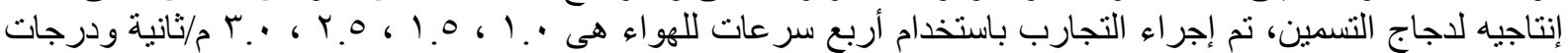

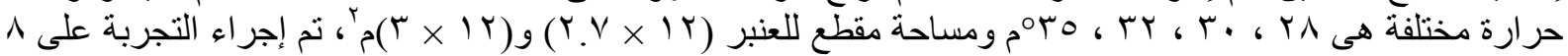

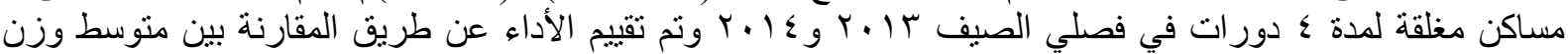

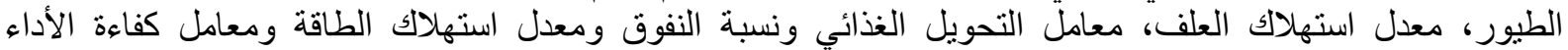

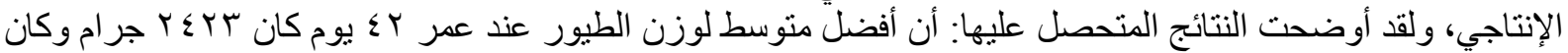

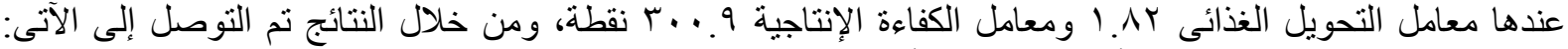

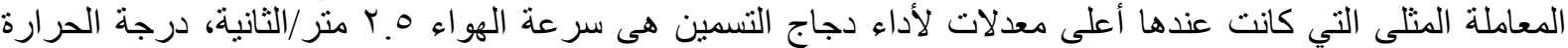

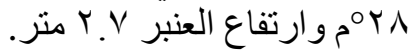

